Proc. Estonian Acad. Sci. Geol., 2000, 49, 1, 17-27

\title{
GRAIN MICROMORPHOLOGY IN THE RANNAMÕISA SECTION, LOWER CAMBRIAN, ESTONIA
}

\author{
Tiia KURVITS ${ }^{\mathrm{a}}$, William C. MAHANEY ${ }^{\mathrm{b}}$, and Volli KALM ${ }^{\mathrm{a}}$
}

a Institute of Geology, University of Tartu, Vanemuise 46, 51014 Tartu, Estonia; kurvi@ut.ee, vkalm@ut.ee

b Geomorphology and Pedology Laboratory, York University, 4700 Keele St., North York, Ontario, Canada L4J 1J4; bmahaney@yorku.ca

Received 6 October 1999, in revised form 24 November 1999

\begin{abstract}
Sand and silt grains of Lower Cambrian siliciclastic rocks in Estonia were studied by the scanning electron microscope and energy dispersive spectrometer to find out if grain micromorphology might prove useful in determining clast sedimentologic and diagenetic history. The majority of grains studied fall in the range of 40-70 $\mu \mathrm{m}$ diameter, have angular shapes, and show considerable dissolution. The predominant minerals, quartz with minor amounts of K-feldspar are cemented by silica. Quite possibly these aggregates are the result of fluctuating water tables in weathering conditions over a long period of time. Prevalent etching on most grain surfaces obscures microfeatures that might reveal exact transport histories.

Grain shape, size, and sorting, also sedimentary structures suggest the material of sandstones at Rannamõisa was transported into the sedimentary basin mainly in suspension, aeolian and/or fluvial, which permitted no rounding of grains.
\end{abstract}

Key words: grain micromorphology, sandstones, silica, weathering, sedimentology, Lower Cambrian, Estonia.

\section{INTRODUCTION}

Grains from Devonian and Cambrian sandstone beds in Estonia have been studied (Mahaney \& Kalm 2000) to elicit information on micromorphology and composition, relative to overlying tills of Quaternary age, that might prove useful in environmental discrimination. As part of this study the Rannamõisa section (Fig. 1) was included to gain information on sands of Lower Cambrian age that might have been incorporated into Quaternary tills. The grain microtextures and shape, also grain size, composition of sands, including cement of mineral 
aggregates in the Lower Cambrian sandstones alone were studied to determine if provenance, mode of transport, and Phanerozoic diagenetic history could be reconstructed.

Sand grain micromorphology has been studied with the light microscope by many researchers (see, for example, Karlström 1988; Ghosh 1997). During the last 30 years the imaging of grains studied with the scanning electron microscope (SEM) has made it possible to reconstruct multiple environmental histories (Krinsley \& Smalley 1972), wind velocity (Krinsley \& Wellendorf 1980), weathering and diagenetic histories (Krinsley \& Doornkamp 1973; Mahaney 1990, 1992; Mahaney \& Rutter 1992), metamorphic alteration (Retallack \& Krinsley 1993), and palaeoclimate (Mahaney 1990; Mahaney \& Kalm 1995, 2000; Krinsley \& Marshall 1987). Also, there is considerable potential to use the SEM and the energy dispersive spectrometer (EDS) in the study of sand grain surface microfeatures, both to establish the composition of the grains and coatings, and to gain an overall assessment of roundness vs. angularity. Additional fracture and abrasion microtextures provide important evidence of the damage inflicted on sands during transport by different geologic agents.

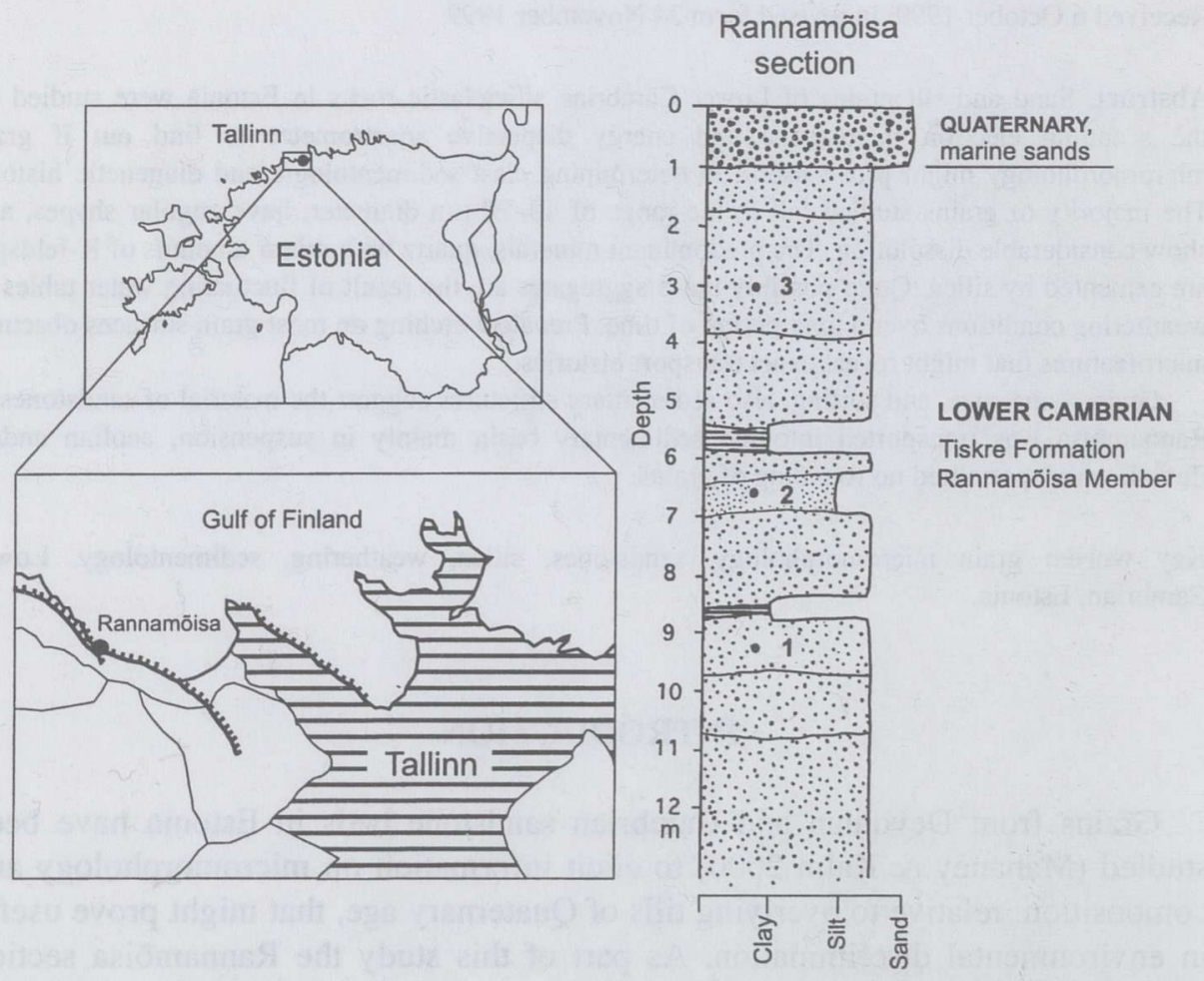

Fig. 1. Location of the Rannamõisa section (northern Estonia) and sedimentological log showing sampling sites. 


\section{FIELD LOCALITY AND MATERIAL}

Numerous sections of noncemented siliciclastic sand- and siltstones of Lower Cambrian age, up to $20 \mathrm{~m}$ in thickness (Mens \& Pirrus 1977), crop out on the North Estonian coast along the south shore of the Gulf of Finland. The finegrained sandstones of the Tiskre Formation form the best outcropping upper part of them. Tiskre sandstones were formed in a restricted area during a regressive evolutionary stage of the Baltic Basin in late Early Cambrian time (Mens \& Pirrus 1997). Orientation and dipping of sedimentary structures found in some Tiskre beds on the Gulf of Finland coast (Pirrus 1978) indicate an ancient coastline with the mainland to the south and southeast. This mainland, 200-300 $\mathrm{km}$ from Rannamõisa, covered with Lower Cambrian silt- and claystone, provided the main source material in Tiskre time.

The easily accessible Rannamõisa section of the Tiskre Formation, located $14 \mathrm{~km}$ west of Tallinn (Fig. 1), was chosen for investigation. The section (12 m thick) consists of massive, horizontally bedded, well-sorted and very finegrained, silty quartzitic sandstones with thin interbeds of silt- and claystone in the interval from 5.5 to $8.7 \mathrm{~m}$. Massive beds, up to $1.0 \mathrm{~m}$ thick, do not show any distinct internal laminae sets. Horizontal bedding, formed by alternation of thick massive silty sandstone and very thin clay beds or visible only by discontinuity surfaces, shows weak, large-scale undulation. Coarse massive marine sands of Quaternary age cap the Lower Cambrian rocks with a thickness of $1 \mathrm{~m}$ (Fig. 1).

Several thousand grains were analysed from three levels - the bottom (sample 1), middle (sample 2), and top (sample 3) of the section (Fig. 1). Sixty grains per sample were analysed in detail.

\section{METHODS}

Collected samples were disaggregated and sieved to determine the degree of sorting. All samples were wet sieved with $63 \mu \mathrm{m}$ sieves. The portion passing the $63 \mu \mathrm{m}$ sieve was subjected to analysis by a hydrometer (Day 1965). The samples were later split to provide representative samples for SEM and EDS analyses. From the representative sample groups, grains were selected randomly and sprinkled on aluminium stubs, coated with graphite colloidal cement, let dry, and coated with gold-palladium. These stubs were analysed to obtain relative information on grain shape and to study the larger mineral aggregates.

After obtaining the first run of information on mineral composition, a second group of samples were collected randomly from the sample splits. Individual grains were first examined under a light microscope and then mounted to study their surfaces for microtextural features and coatings of various kinds. Representative photomicrographs were later selected (Pls. I, II). 


\section{RESULTS AND DISCUSSION}

\section{Grain size and composition}

In all three samples grains fall in the range of $40-70 \mu \mathrm{m}$, that is, belong to very coarse silt and very fine sand fractions. The strict fractionation of grains corresponds to a high degree of sorting. If there is any clay present, it is bound up in the coatings and cement holding individual grains together.

The grain size data from the Rannamõisa section are close to grain size characteristics of the whole Tiskre Formation (excluding clay beds), which fall in the wider range of $10-200 \mu \mathrm{m}$, whereas the mean grain size is a little coarser, reaching about $80 \mu \mathrm{m}$ (Loog 1963). The whole grain size spectrum has positive skewness, is well sorted, and very similar to aeolian or fluvial deposits. The lack of clay in the Tiskre sediments, where parent rocks are rich in it, may indicate wind action carrying clay particles far away and concentrating grains in the very fine sand and coarse silt fractions.

The mineral composition of all grains studied includes mainly quartz (c. 70\%) with minor amounts of $\mathrm{K}$-feldspar (c.30\%) and few grains of mica, indicating that this material is derived primarily from sedimentary rock. The scarcity of mica compared to source sediments can be explained by wind transport. No heavy minerals were recovered in the coarse laboratory separation process, although some were noted in the bulk samples.

\section{Chemical weathering and cementation}

There were no fresh grains encountered, because chemical weathering was strong enough to obliterate surface microtextures. This complicates the use of fracture and abrasion microfeatures in reconstructing the environmental history.

\section{Explanation of Plate I}

Fig. 1. Indurated angular grains of $\mathrm{K}$-feldspar with extreme dissolution (sample 1).

Fig. 2. Etched K-feldspar in the centre, surrounded by quartz showing extreme dissolution (sample 3).

Fig. 3. Well-weathered K-feldspar (sample 3).

Fig. 4. Cluster of angular grains showing extreme forms of weathering; K-feldspar to the left, quartz to the right (sample 1).

Fig. 5. Well-weathered quartz particle about $50 \mu \mathrm{m}$ in diameter resting on $\mathrm{K}$-feldspar, showing etching along cleavage planes (sample 2).

Fig. 6. Grain to the right is K-feldspar with etching following cleavage planes. Grain to the left is quartz showing extreme dissolution. Centre of the quartz grain has intergrowth of rutile showing a high Ti spike on the energy dispersive spectrometer (sample 2).

Fig. 7. K-feldspar (top) and quartz (centre and bottom) (sample 2).

Fig. 8. Quartz showing a high degree of dissolution (sample 3). 
PLATE I
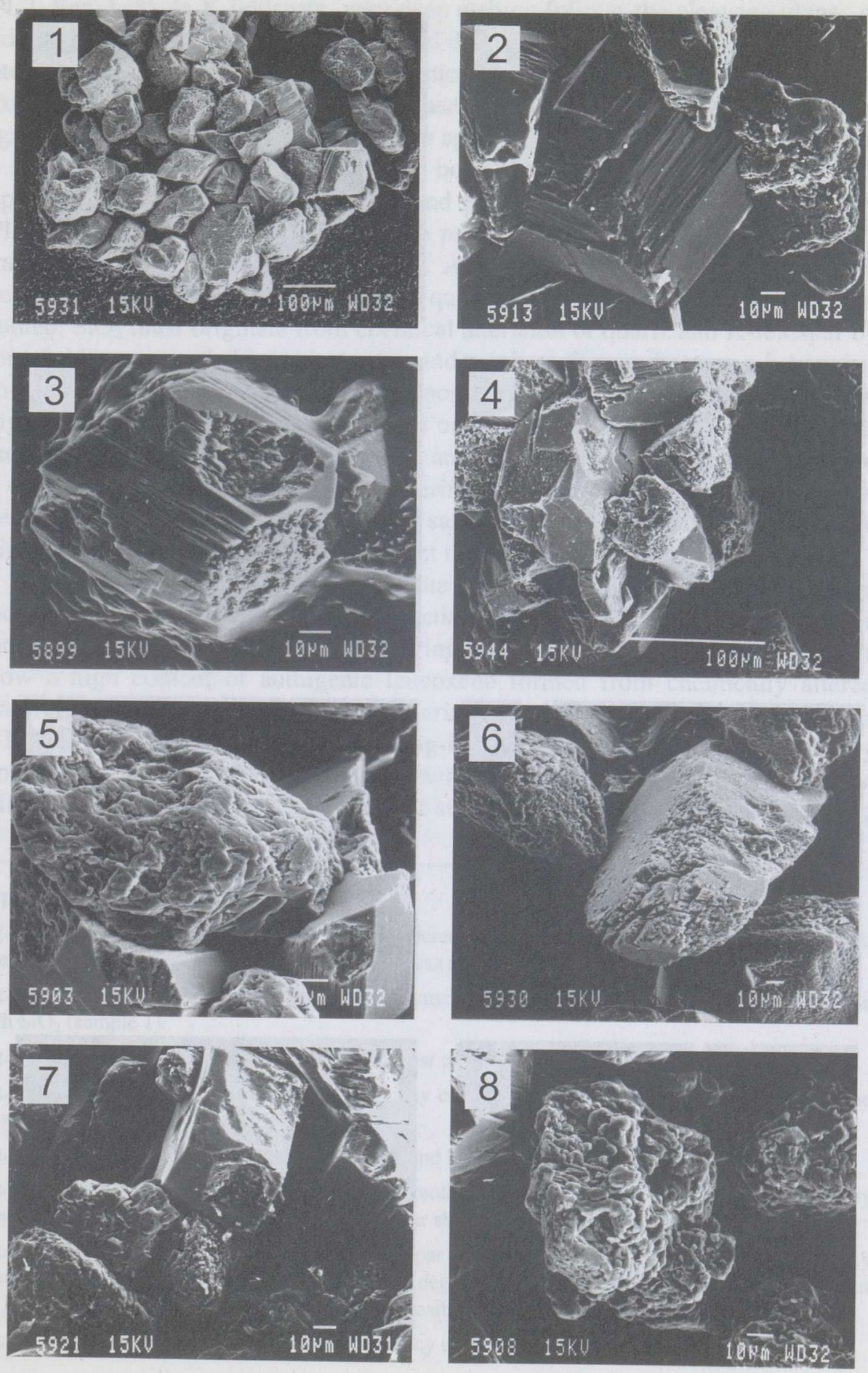

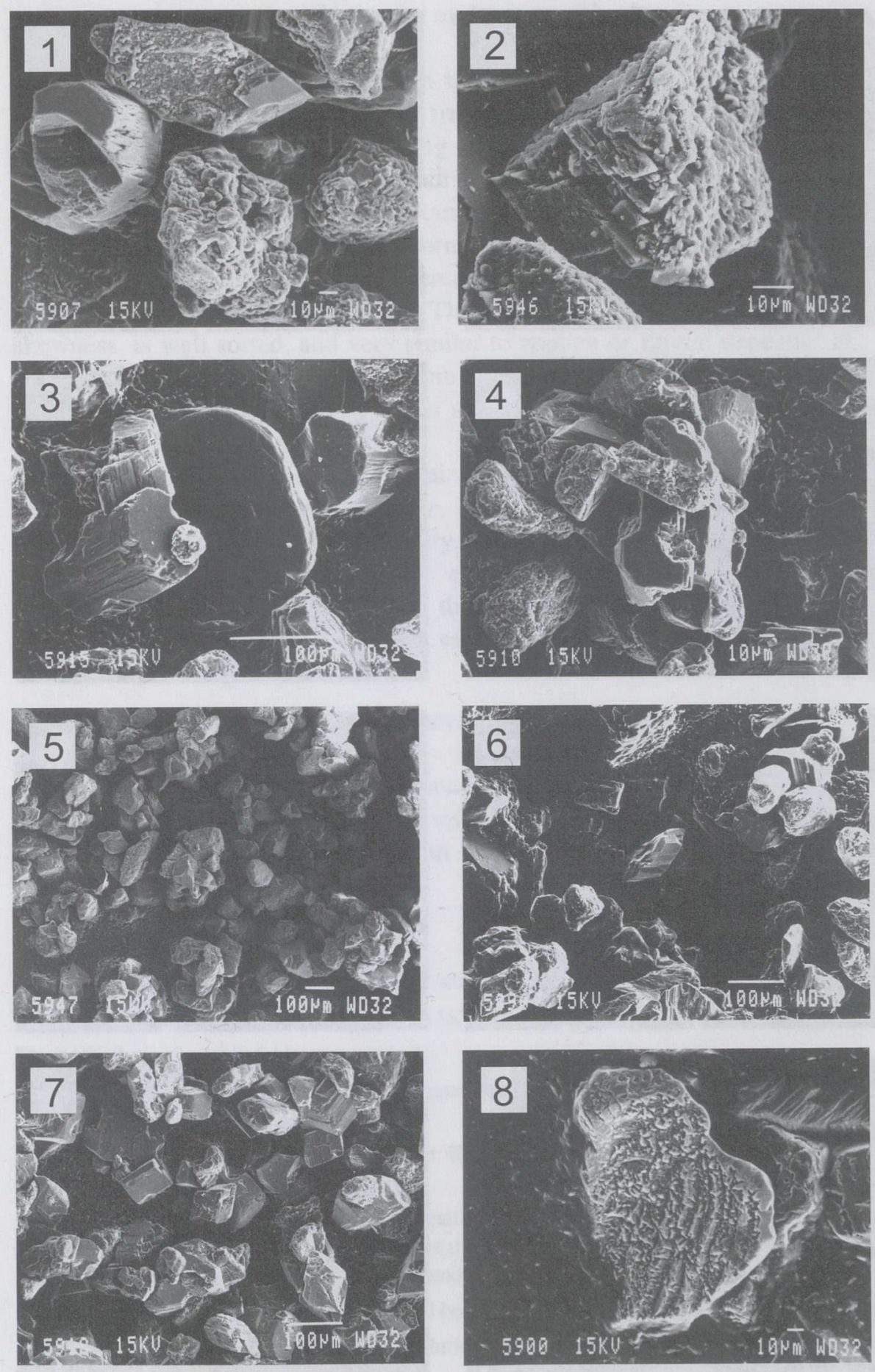
Extreme dissolution of $\mathrm{K}$-feldspar and quartz is prevalent on all grains studied (Pl. I, figs. 1-8). In K-feldspars, very deep etching follows the cleavage planes of individual minerals, with both shallow and deep microfeatures extending very deep into some grains ( $\mathrm{Pl}$. I, figs. 2, 3). Chemical weathering of quartz has led to the production of deep pits, which in many cases has nearly obliterated the grain (Pl. I, figs. 5-8). Etched features are common on approximately $75 \%$ of all grains studied.

Some of the liberated silica, from both quartz and K-feldspar, has been reprecipitated on the weathered quartz and feldspar grains as authigenic coatings (P1. II, figs. 1, 2). Coatings of silica are prevalent on approximately $25 \%$ of all grains and highly prevalent in sample 1. Aggregates of grains (Pl. II, figs. 3-5) are all loosely cemented with $\mathrm{SiO}_{2}$. Since quartz is predominating among the grains studied, $\mathrm{SiO}_{2}$ must originate from chemical alteration of quartz and $\mathrm{K}$-feldspar by pore fluids, most probably with waxing and waning of groundwater and changing Eh-pH conditions. Such fluctuations, more common in coarser arkosic sands, might also lead to rapid release of silica on a greater surface area of finer sands like those present at Rannamõisa. Ingress and egress of pore water could be related to downcutting by surface streams lowering the water table and channelling of meteoric water through the coarser cap sands at the surface. Silica coatings are thick and thereby most probably represent time frames of millions of years.

There are no sediments representing the time interval between Early Cambrian and early Late Cambrian in North Estonia in the area of the Tiskre beds. The contact of Tiskre sandstones with overlying beds is erosional. Mineralogical data show a high content of authigenic leucoxene formed from chemically altered titaniferous minerals and from in weathering processes unstable ilmenite (Mens $\&$ Pirrus 1977). It is assumed that a long-lasting hiatus exists between partially eroded Lower Cambrian rocks and newly deposited Upper Cambrian sands, following a period of weathering. This supports the interpretations of etching

\section{Explanation of Plate II}

Fig. 1. One K-feldspar to the left and two weathered quartz grains at the bottom and to the right. The grain at the top is K-feldspar with a fresh quartz shell armouring it (sample 3).

Fig. 2. Quartz intergrowth with K-feldspars. Quartz shows dissolution effects and reprecipitation with $\mathrm{SiO}_{2}$ (sample 1).

Fig. 3. Weakly cemented (silica cement) K-feldspar and quartz (sample 2).

Fig. 4. Aggregate of mainly quartz grains, weakly cemented with $\mathrm{SiO}_{2}$. Etching is pronounced on all surfaces (sample 2).

Fig. 5. Indurated aggregate of subangular quartz and K-feldspar (sample 1).

Fig. 6. General frame of grains with a high percentage of weathered ones. The grains are largely quartz and feldspar with predominantly subangular shape (sample 1).

Fig. 7. General frame of sample 2 with K-feldspar in the centre surrounded by a mix of largely quartz and K-feldspar. The grains show a similar degree of angularity compared with sample 1, but are less weathered, the proportions of fresh and weathered surfaces being equal.

Fig. 8. Quartz with highly weathered low-frequency deep fractures of unknown origin (sample 3). 
features of quartz and $\mathrm{K}$-feldspar grains and lack of prominent microtextures as grains have been highly weathered postdepositionally in place of deposition.

Micas, infrequently encountered (less than 1\%) among the population of minerals present, indicate little chance of finding clay mineral coatings on grain surfaces. Approximately 20 coatings on various grains were studied with the EDS and all had a composition of $\mathrm{SiO}_{2}$ only, either amorphous or crystalline, most probably wreckages from diagenetic weathering of quartz and $\mathrm{K}$-feldspar.

\section{Shape of grains}

Regardless of the presence of weathering microtextures, the most outstanding feature of the grains in this section is their angularity (Pl. II, figs. 5-7). Unlike sands investigated in Devonian outcrops $100 \mathrm{~km}$ to the south (Mahaney \& Kalm 2000 ), there are no round grains in the Rannamõisa section. All three samples showed either angular or subangular grains. This is partially caused by the smaller grain size of the Tiskre samples compared to Devonian sands, because quartz grains smaller than $125 \mu \mathrm{m}$ are not much rounded at all (Blatt 1970). The grain size of $<50 \mu \mathrm{m}$, at which the effects of attrition become considerably reduced (see Leeder 1982), seems more reliable. Also, Viiding \& Konsa (1976) studied quartz grain morphology of Lower Cambrian rocks and established a decrease in angularity in the $50-100 \mu \mathrm{m}$ fraction, and an increase in subrounded grains in coarser fractions. Thus, although the rounding of quartz is not intensive, the process of attrition works in Lower Cambrian very fine sand fractions.

The fact that all grains studied are angular or subangular indicates that the transport distance must have been short or the transport path does not cause essential mechanical wastage, thus material has been transported in suspension. Since transport of sediments by beadload or by traction in water would leave grains with edges rounded and surfaces full of $\mathrm{v}$-shaped percussion scars (Krinsley \& Doornkamp 1973), it can be ruled out as a major factor responsible for deposition of investigated grains. The angularity of the grains is similar to mass wasted material (Bull et al. 1987) and to aeolian grains, as discussed by Krinsley \& Wellendorf (1980). Quartz and orthoclase sands in the Navajo sandstone, of Jurassic age, in the southwestern United States (Mahaney unpublished) also exhibit extreme angularity despite aeolian transport from a source in Idaho, $1000 \mathrm{~km}$ to the north.

No evidence of glacial transport was detected in the several thousand grains studied. There was only one grain with remnant conchoidal fractures (Pl. II, fig. 8).

From the grain shape, size, and sorting of Tiskre sands, we may assume their transportation occurred in suspensions, either aeolian or possibly augmented by streamwater transport. Although there were no structures evidently belonging to aeolian sedimentation, the transporting agent could be air. According to Einsele (1992), the fraction $40-70 \mu \mathrm{m}$ can be transported by moderate storms as shortterm suspensions in air up to several tens of kilometres. The material carried in 
suspension may settle down in shallow water near the mainland, with storm waves transporting it to the deeper water, forming massive beds. This type of structure, forming in outer parts of the shoreface, below everyday wave base (Friedman et al. 1992) may escape mechanical destruction of grains. These conditions favour the formation of massive bedding, similar to beds in the Tiskre Formation, and could contribute to preserving the angularity of quartz and Kfeldspar grains. It has been suggested that massive beds, lacking any lamination, are formed either by very rapid deposition from suspension, or by deposition from very highly concentrated sediment dispersions (Blatt et al. 1980), thus, with low mechanical attrition.

\section{CONCLUSIONS}

Grain micromorphological analysis of the Lower Cambrian siliciclastic rocks in the Rannamõisa section of northern Estonia shows clast size of $40-70 \mu \mathrm{m}$ coarse silt and very fine sand and a well-sorted material derived from a sedimentary precursor.

All the grains are with moderate to extreme chemical etching, and dissolution of the grains is postdepositional in age. Fine sand aggregates consisting of quartz and K-feldspar, weakly indurated and cemented with silica, are the result of fluctuating groundwater table over long periods during post-Tiskre hiatuses in Late Cambrian or Middle Cambrian time. Frequent inundation caused by a rising water table, followed by lowering, would lead to rapid release of $\mathrm{SiO}_{2}$ into pore waters, and its subsequent precipitation with changing Eh-pH conditions.

While extreme chemical alteration of the grains did not allow exact microtextural analysis, grain size, sorting, and angular to subangular shape suggest transport in suspension, either aeolian and/or fluvial. Sedimentary structures, that is, massive beds lacking any lamination, support the idea of very rapid deposition from suspension. This may have occurred during storms generating backflow carrying material from shore to a depth below everyday wave base. Suspensiondominated transport apparently permitted no rounding of grains.

\section{ACKNOWLEDGEMENTS}

We are deeply indebted to Rein Vaikmäe for introducing W. C. Mahaney to the northern Estonian coast and for many kindnesses during his several visits in the late 1980 s and early 1990 s. Thanks are extended to Kaisa Mens for revising the paper and useful comments. Funding for the analytical work was provided by Quaternary Surveys, Toronto. Caitlin Mahaney assisted with the laboratory work in the Geomorphology and Pedology Laboratory at York University. The investigation was also supported by Estonian Science Foundation (grant No. 3237 ) and research project TBGGL 0550. 


\section{REFERENCES}

Blatt, H. 1970. Determination of mean sediment thickness in the crust: a sedimentologic method. GSA Bull., 81, 255-262.

Blatt, H., Middleton, G. \& Murray, R. 1980. Origin of Sedimentary Rocks, 2nd ed. Prentice-Hall, Englewood Cliffs.

Bull, P. A., Goudie, A. S., Williams, D. P. \& Watson, A. 1987. Colluvium: a scanning electron microscope analysis of a neglected sediment type. In Clastic Particles (Marshall, J. R., ed.), pp. 16-35. Van Nostrand Reinhold, New York.

Day, P. E. 1965. Particle fractionation and particle size analysis. In Methods of Soil Analysis (Black, C. A., ed.), pp. 545-567. American Soc. Agronomy, Madison, Wisconsin.

Einsele, G. 1992. Sedimentary Basins: Evolution, Facies, and Sediment Budget. Springer-Verlag, Berlin.

Friedman, G. M., Sanders, J. F. \& Kopaska-Merkel, D. C. 1992. Principles of Sedimentary Deposits: Stratigraphy and Sedimentology. Macmillan, New York.

Ghosh, P. 1997. Geomorphology and palaeoclimatology of some Upper Cretaceous palaeosols in central India. Sedim. Geol., 110, 25-49.

Karlström, E. T. 1988. Multiple paleosols in pre-Wisconsinan drift, northwestern Montana and southwestern Alberta. Catena, 15, 147-178.

Krinsley, D. H. \& Doornkamp, J. C. 1973. Atlas of Quartz Sand Surface Textures. Cambridge Univ. Pr.

Krinsley, D. H. \& Marshall, J. R. 1987. Colluvium: a scanning electron microscope analysis of a neglected sediment type. In Clastic Particles (Marshall, J. R., ed.), pp. 2-15. Van Nostrand Reinhold, New York.

Krinsley, D. H. \& Smalley, I. J. 1972. Sand. Am. Sci., 60, 286-291.

Krinsley, D. H. \& Wellendorf, W. 1980. Wind velocities determined from the surface textures of sand grains. Nature, 283, 372-373.

Leeder, M. R. 1982. Sedimentology: Process and Product. Allen \& Unwin, London.

Loog, A. 1963. On granulometric and mineralogic composition of rocks of Tiskre stage and Ülgase and Maardu members. ENSV TA Toim. Fü̈̈s. Matem. Tehn., 12, 334-337.

Mahaney, W. C. 1990. Ice on the Equator. Wm. Caxton, Ellison Bay, Wisconsin.

Mahaney, W. C. 1992. Weathering and geochronology of a Quaternary paleosol sequence in lower Teleki Valley, Mount Kenya. Catena, 19, 99-118.

Mahaney, W. C. \& Kalm, V. 1995. Scanning electron microscopy of Pleistocene tills in Estonia. Boreas, 24, 13-29.

Mahaney, W. C. \& Kalm, V. 2000. Comparative SEM study of oriented till blocks, glacial grains, and Devonian sands in Estonia and Latvia. Boreas (in press).

Mahaney, W. C. \& Rutter, N. W. 1992. Relative ages of the moraines of the Dalijia Shan, northwestern China. Catena, 19, 179-191.

Mens, K. \& Pirrus, E. 1977. Stratotypes of the Cambrian Formations of Estonia. Valgus, Tallinn (in Russian).

Mens, K. \& Pirrus, E. 1997. Formation of the territory: Vendian-Tremadoc clastogenic sedimentation basins. In Geology and Mineral Resources of Estonia (Raukas, A. \& Teedumäe, A., ed.), pp. 184-191. Estonian Acad. Publ., Tallinn.

Pirrus, E. 1978. The use of orientated structures for a reconstruction of Cambrian paleogeography in Estonia. ENSV TA Toim. Geol., 27, 35-41 (in Russian).

Retallack, G. J. and Krinsley, D. H. 1993. Metamorphic alteration of a Precambrian (2.2 Ga) paleosol from South Africa revealed by backscattered electron imaging. Precambrian Res., 63, 27-41.

Viiding, H. \& Konsa, M. 1976. Data on typomorphic varieties of minerals in terrigenous deposits. In Metodika $i$ interpretatsiya rezul'tatov mineralogicheskikh $i$ geokhimicheskikh issledovanij (Narbutas, V. V., ed.), pp. 60-67. Mokslas, Vilnius (in Russian). 


\title{
TERADE MIKROMORFOLOOGIA RANNAMÕISA LÄBILÕIKES, ALAMKAMBRIUM, EESTI
}

\author{
Tiia KURVITS, William C. MAHANEY ja Volli KALM
}

Skaneeriva elektronmikroskoobi ja energiadispersiivse spektromeetriga uuriti peenliiva ja jämealeuriidi terade mikromorfoloogiat alamkambriumi Tiskre kihistu liivakivides Rannamõisa paljandis. Domineerivad ümardumata, kuid porsunud terad. Kivimis valdavad mineraalid, kvarts ja K-päevakivi moodustavad agregaate, mis on nõrgalt tsementeerunud $\mathrm{SiO}_{2}-$ ga. Tsement ja autigeensed $\mathrm{SiO}_{2-}$ äärised tekkisid ilmselt põhjavee kõikuva taseme ja keemilise murenemise tõttu pika aja vältel. Porsumisnähud raskendavad tera pinna mikrostruktuuri põhjal järelduste tegemist setteosakeste transpordikeskkonna kohta. Terade ümardumata kuju, settekivimi peeneteralisuse, sorteerituse ja massiivsete tekstuuride alusel on järeldatud, et osakeste edasikanne toimus peamiselt suspensioonina tuule ja/või vooluvee toimel.

\section{МИКРОМОРФОЛОГИЯ ЗЕРЕН В ОБНАЖЕНИИ РАННАМЫЙЗА, НИЖНИЙ КЕМБРИЙ, ЭСТОНИЯ}

\author{
Тийа КУРВИТС, Уиллиам МАХЕЙНИ и Волли КАЛМ
}

С помощью сканирующего микроскопа и энергодисперсного спектрометра исследованы микроморфология мелкопесчаной и крупноалевритовой фракции песчаника обнажения Раннамыйза тискреской свиты нижнего кембрия. Установлено, что доминируют неокругленные, со следами выветривания зерна. Преобладающие в породе минералы, кварц и К-полевые шпаты составляют агрегаты, слабоцементированные $\mathrm{SiO}_{2}$. Цемент и аутигенные каемки $\mathrm{SiO}_{2}$ сформировались, вероятно, в результате флюктуации уровня подземных вод и химического выветривания в течение длительного времени. Изменившаяся под влиянием выветривания микротекстура зерен не позволяет сделать вывод о транспортных условиях частиц, однако неокругленная морфология зерен, мелкозернистость, хорошая сортировка и массивная текстура песчаника позволяют считать, что транспорт частиц происходил в суспензии либо в эоловой или/и флювиальной среде. 